\title{
Energy expenditure, urea kinetics, and body weight gain within a segregating resource family population
}

\author{
P. Lahann, ${ }^{* 1}$ J. Voigt, ${ }^{*}$ C. Kühn,† R. Pfuhl,‡ C. C. Metges, ${ }^{*}$ P. Junghans, ${ }^{*}$ U. Schönhusen, ${ }^{*}$ and H. M. Hammon* \\ ${ }^{*}$ Research Unit Nutritional Physiology (“Oskar-Kellner"), \\ †Research Unit Molecular Biology, and \\ †Research Unit Muscle Biology and Growth, Leibniz Institute for Farm Animal Biology (FBN), Wilhelm-Stahl-Allee 2, 18196 Dummerstorf, \\ Germany
}

\section{ABSTRACT}

Beef and dairy cattle represent divergent metabolic types that disseminate nutrients into either meat or milk and differ in nutrient accretion. To investigate nutrient flow and turnover in an animal model combining beef and dairy cattle, a crossbred experiment has been started. An $\mathrm{F}_{2}$ resource population was generated from Charolais (beef breed) sires and German Holstein (dairy breed) cows as $\mathrm{P}_{0}$ founders by consistent use of embryo transfer to establish the $F_{1}$ and $F_{2}$ generations, which accordingly comprised half- and full-sib offspring. In 64 bulls of $5 \mathrm{~F}_{2}$ families, dry matter intake and growth performance were measured monthly, and carcass composition was determined after slaughtering at 18 mo of age. Energy expenditure and urea kinetics were investigated via stable isotope tracer techniques using an intravenous single bolus dose of sodium $\left[{ }^{13} \mathrm{C}\right]$ bicarbonate $[2.5 \mu \mathrm{mol} / \mathrm{kg}$ of body weight (BW), 99 atom\% $\left.{ }^{13} \mathrm{C}\right]$ at 8 and $18 \mathrm{mo}$ of age and of $\left[{ }^{15} \mathrm{~N}\right]$ urea $(0.28 \mathrm{mg} /$ $\mathrm{kg}$ of BW, 99 atom $\%{ }^{15} \mathrm{~N}$ ) at 8 mo of age, respectively. Insulin responses were measured via glucose tolerances tests at the age of $8 \mathrm{mo}$. The results revealed significant differences between families for growth performance, energy expenditure, and urea kinetics. In summary, low energy expenditure was associated with high average body mass gain and high insulin response. A greater urea loss was associated with reduced muscle protein in carcass. In addition, corresponding half-sib and full-sib sisters from bulls with highest growth rate indicated highest milk production. In conclusion, we have demonstrated that differences in energy expenditure and urea kinetics result in differences in average daily gain and carcass traits and vice versa in $\mathrm{F}_{2}$ crossbred bulls with common beef and dairy genetic backgrounds.

Key words: bull, energy expenditure, urea kinetics, cross breeding

Received October 8, 2009.

Accepted May 23, 2010.

${ }^{1}$ Corresponding author: lahann@fbn-dummerstorf.de

\section{INTRODUCTION}

Cattle breeds are generally selected preferentially for milk or meat production. Dairy and beef cattle differ in the way in which they disseminate nutrients. Dairy cows direct more nutrients toward the mammary gland for milk production than do beef cows (Pareek et al., 2007). Concerning growth, differences exist in growth rate, meat and fat accretion, and carcass composition between beef and dairy breeds (Istasse et al., 1990; Pfuhl et al., 2007; Zitnan et al., 2008). The main underlying factors for the differences in partitioning and the type of nutrient flow seem to be based on genetic differences and specific nutrition-gene interactions (Bauman and Currie, 1980; Cronjé, 2000). However, the physiological regulation of nutrient partitioning and dissemination in either muscle or fat tissue are still not completely understood. Thus, to investigate the variability of the regulation and quantification of nutrient flow and nutrient turnover in cattle, we used $\mathrm{F}_{2}$ resource families, which were generated by crossing Charolais bulls and German Holstein cows (Kühn et al., 2002). German Holstein and Charolais represent breeds of comparable size but bulls differ in growth rate and accretion of protein and fat. Charolais bulls had higher growth rates and protein accretion, whereas German Holstein bulls had a higher fat accretion in the carcass (Bellmann et al., 2004b; Pfuhl et al., 2007). In addition, German Holstein cows are known for their high milk yield, whereas Charolais cows have low milk yield (Kühn et al., 2002; Pareek et al., 2007). Besides gross phenotypic differences (Pfuhl et al., 2007), both founder breeds differ distinctly in their nutrient metabolism (Bellmann et al., 2004a,b; Pareek et al., 2007) as well as in their mucosal morphology and small intestine mass (Zitnan et al., 2008), providing the means to compare different metabolic types. The use of the $\mathrm{F}_{2}$ design enabled us to study the divergent nutrient dissemination in a combined dairy and beef genetic background (Kühn et al., 2002). As environmental conditions in the resource population are not different, differences in nutrient flow should primarily reflect differences of divergent metabolic regulation. The determination of nutrient accre- 
tion in relation to expenditure of metabolizable energy in bulls with a broad varying genetic background will provide new insight in regulation of nutrient partitioning.

Earlier physiological investigations in the founder breeds and the half-sib $F_{2}$ resource families have focused mainly on milk production in heifers and cows, showing remarkable differences in milk yield and associated hormones among founder breeds and among $\mathrm{F}_{2}$ resource families (Pareek et al., 2007; Hammon et al., 2007, 2010). Still, almost nothing is known about the partitioning of nutrients in body tissues in respective fattened $\mathrm{F}_{2}$ bulls, although the understanding of nutrient pathways would be valuable for improved meat production and may in addition provide a link with variation in milk production in their $\mathrm{F}_{2}$ sisters.

Thus, we aimed to characterize the differences in growth performance between bulls of 5 half-sib German Holstein $\times$ Charolais $\mathrm{F}_{2}$ crossbred families and linked these traits to possible differences in energy expenditure and nitrogen metabolism. We hypothesized that differences in growth performance and carcass composition should be reflected by changes in energy expenditure and urea kinetics and may provide associations to $\mathrm{F}_{2}$ full-sib and half-sib females.

\section{MATERIALS AND METHODS}

\section{Experimental Model}

A breeding model as described by Kühn et al. (2002) was chosen to investigate the genetic and physiological background of phenotypic variability among animals of different nutrient turnover with respect to beef and dairy cattle. The $\mathrm{F}_{2}$ resource population investigated in this study was based on 5 Charolais bulls (named $\mathrm{A}, \mathrm{B}, \mathrm{C}, \mathrm{D}$, and E), which were mated to 20 German Holstein cows per bull by means of multiple ovulation and embryo transfer at the Leibniz Institute for Farm Animal Biology (FBN) in Dummerstorf, Germany. An intercross of the $\mathrm{F}_{1}$ individuals was performed using embryo transfer to German Holstein recipients to establish full-sib and half-sib $\mathrm{F}_{2}$ offspring (Kühn et al., 2002; Hammon et al., 2007). The $64 \mathrm{~F}_{2}$ bulls investigated comprised 5 paternal half-sib families: $\mathrm{Ab}(\mathrm{n}=10)$, Ba $(\mathrm{n}=14), \operatorname{Cd}(\mathrm{n}=14)$, De $(\mathrm{n}=8)$, and Ec $(\mathrm{n}=18)$. The uppercase letter represents the paternal origin of the $\mathrm{F}_{1}$ male and the lowercase letter represents paternal origin of the $\mathrm{F}_{1}$ female according to the $\mathrm{P}_{0}$ Charolais sires $\mathrm{A}, \mathrm{B}, \mathrm{C}, \mathrm{D}$, and $\mathrm{E}$.

\section{Animals, Husbandry, and Feeding}

Male calves were raised on a milk replacer diet from 7 to $107 \mathrm{~d}$ of age with increasing supplementation of grass hay and concentrate. From 4 to 18 mo of age, the animals were tethered on individual feeding places with a semi-slatted floor and automatic drinking bowls. The daily feed ration was offered ad libitum and was composed of chopped grass hay, containing $11 \% \mathrm{CP}$ and $32 \%$ crude fiber, and a concentrate (RM 2007: mixture of barley, molasses chips, soybean extraction meal, molasses, minerals and vitamin premix: Vollkraft Mischfutterwerke GmbH, Rendsburg, Germany), containing $15 \% \mathrm{CP}, 2 \%$ crude fat, $9 \%$ crude fiber, $0.8 \% \mathrm{Ca}$, $0.3 \% \mathrm{P}$, and $0.3 \% \mathrm{Na}$. The feed proportioning of hay and concentrate was 1:3 (2.96 \pm 0.09 ; based on air DM) resulting in a calculated energy content of $12.7 \mathrm{MJ}$ of $\mathrm{ME} / \mathrm{kg} \mathrm{DM}$ of feed $(\mathrm{AfB}, 1998)$ and $13.2 \mathrm{~g}$ of $\mathrm{CP} / \mathrm{MJ}$ of ME. Any unconsumed feed was removed, weighed, and recorded daily. The bulls were weighed monthly. The feed conversion rate (FCR) was expressed as DMI per unit of ADG. The bulls were slaughtered at 18 mo of age in the abattoir of the institute according to a standardized protocol. All animals were cared for and killed according to German law and regulations for animal care. Experimental procedures were approved by the institutional authorities and by the responsible office of the State of Mecklenburg-Vorpommern, Germany.

\section{Infusion, Blood Sampling, and Analyses}

Whole-body energy expenditure at 8 and 18 mo of age and urea kinetics at 8 mo of age were determined via stable isotope tracer techniques, using $\left[{ }^{13} \mathrm{C}\right]$ sodium bicarbonate to determine energy expenditure (Junghans et al., 1997, 2007; Lachica and Aguilera, 2003) and doubly labeled $\left[{ }^{15} \mathrm{~N}_{2}\right]$ urea to trace urea excretion (Nolan and Leng, 1974; Merchen, 1993; Lapierre and Lobley, 2001). After a 12-h fast, a catheter (Braun, Certofix Mono 340, Melsungen, Germany) was inserted into the right jugular vein for tracer application and blood sampling. An intravenous bolus of $\left.\mathrm{NaH}^{13}{ }^{13}\right] \mathrm{O}_{3}$ $\left(2.5 \mu \mathrm{mol} / \mathrm{kg}\right.$ of BW, 99 atom $\%{ }^{13} \mathrm{C}$; Chemotrade Ltd., Leipzig, Germany) and $\left[{ }^{15} \mathrm{~N}_{2}\right]$ urea $(0.28 \mathrm{mg} / \mathrm{kg}$ of BW, 95 atom $\%{ }^{15} \mathrm{~N}$, Berlin-Chemie, Berlin, Germany) was infused, followed by about $10 \mathrm{~mL}$ of saline to ensure complete tracer infusion and catheter washing. The tracers were dissolved in $10 \mathrm{~mL}$ of $0.9 \%$ saline and filtered through a $0.2-\mu \mathrm{m}$ filter before i.v. administration. Blood samples were taken from the jugular vein in tubes (Monovette, Sarstedt, Nümbrecht, Germany) containing Li-heparinate before and 1, 2, 3, 4, 5, 10, 20, 30, 60, 120, and 240 min after $\left.\mathrm{NaH}^{13}{ }^{13} \mathrm{C}\right] \mathrm{O}_{3}$ bolus injection and before and 3, 5, 10, 15, 20, 30, 45, 60, 90, $120,150,180,240,360$, and $480 \mathrm{~min}$ after $\left[{ }^{15} \mathrm{~N}_{2}\right]$ urea bolus injection.

Urea Kinetics. Monovette tubes were placed on crushed ice until centrifuged at $1,450 \times g$ for $15 \mathrm{~min}$ at 
$4^{\circ} \mathrm{C}$. Supernatants were collected and plasma aliquots were stored at $-20^{\circ} \mathrm{C}$ until analysis. Urea concentrations in plasma were measured by urea hydrolyzation with urease to $\mathrm{NH}_{3}$. Subsequently, $\mathrm{NH}_{3}$ was isolated by microdiffusion and was determined via measurements of $\mathrm{NH}_{3}$ (Voigt and Steger, 1967). For analysis of the ${ }^{15} \mathrm{~N}:{ }^{14} \mathrm{~N}$ ratio in plasma urea, $500 \mu \mathrm{L}$ of plasma was incubated with $1 \mathrm{~mL}$ of an urease containing $\mathrm{KH}_{2^{-}}$ phosphate: $\mathrm{Na}_{2} \mathrm{H}$-phosphate buffer $(66.7 \mathrm{mM})$ at $\mathrm{pH} 7.0$ for $3 \mathrm{~h}$ at $40^{\circ} \mathrm{C}$. The resultant $\mathrm{NH}_{3}$ was separated by microdiffusion (Voigt and Steger, 1967), taken up in $5 \mathrm{~mL}$ of $0.01 \mathrm{M} \mathrm{HCl}$, and prepared for measurement of the ${ }^{15} \mathrm{~N}:{ }^{14} \mathrm{~N}$ ratio by evaporation $\left(80^{\circ} \mathrm{C}\right.$, air-forced oven) until dryness. The ${ }^{15} \mathrm{~N}:{ }^{14} \mathrm{~N}$ ratios were measured by means of an isotope ratio mass spectrometer (Delta S, Finnigan MAT, Bremen, Germany) after combustion of the samples by an elemental analyzer (Carlo Erba, Milan, Italy). Sample amounts equivalent to 50 to 100 $\mu \mathrm{g}$ of $\mathrm{N}$ were used for combustion. The ${ }^{15} \mathrm{~N}:{ }^{14} \mathrm{~N}$ ratio was measured against a standard gas, which was calibrated against atmospheric air nitrogen with ammonium sulfate as reference. The ${ }^{15} \mathrm{~N}$-enrichments are expressed as atom percent excess (APE). The APE was calculated by differences between the ${ }^{15} \mathrm{~N}$-enrichments of each blood sample at the different time points after infusion and the ${ }^{15} \mathrm{~N}$-enrichment of urea before infusion. Urea kinetics (urea pool sizes, urea irreversible loss rates, and urea flux) were calculated from the dilution curve of ${ }^{15} \mathrm{~N}$ atom percentages excess in plasma after injection of the isotopes using the method described by Nolan and Leng (1974).

Assuming that the pool size remains constant and the rate of inflow of material is equal to the rate of outflow, the change in isotope ratio (E) in a primary pool with time after a single injection of isotope tracer is given by a multi-exponential curve of the form

$$
\sum_{i=t}^{n} A_{i} e^{-\mathrm{m}_{i} t}
$$

where $t=$ time, $A=$ zero-time intercept of each exponential component, $\mathrm{m}=$ rate constant of each component, $n=$ number of components, and $i=$ component number. From this equation, the following can be calculated:

$$
Q=\frac{P}{\sum_{i=1}^{n} A_{i}},
$$

where $Q$ is the size of the primary compartment (pool) and $P$ is the number of ${ }^{15} \mathrm{~N}$ atoms injected. The total flux rate $(F)$ is the rate (mass/unit time) at which all tracer enters and leaves a primary compartment and which is in steady state given by

$$
F=Q\left(\sum_{i=1}^{n} A_{i}^{\prime} \mathrm{m}_{i}\right),
$$

where $A_{i}^{\prime}$ are fractional zero-time intercepts (Nolan and Leng, 1974).

The irreversible loss rate $(\mathrm{L})$ is that fraction of the total flux rate (mass/unit time) through the primary compartment that leaves but does not return: $\mathrm{L}=\mathrm{P} /$ area under the curve.

The calculation of urea pool sizes, urea flux, and urea loss provides important information on turnover rates of ureagenesis and offers the possibility to make quantitative estimates of nitrogen metabolism in animals. In general, parameters of urea kinetics are strongly influenced by food intake, but animal variation also has effects, such as genetic differences in digestive or metabolic efficiency (Reynolds and Kristensen, 2008).

Energy Expenditure. To determine the ${ }^{13} \mathrm{C}$ abundance in blood $\mathrm{CO}_{2}$ (representing all acid-volatile $\mathrm{CO}_{2}$ ), $0.5 \mathrm{~mL}$ of heparinized whole blood was immediately transferred to a 13-mL glass tube (Exetainer, Labco Ltd., Buckinghamshire, UK), treated with $1 \mathrm{~mL}$ of lactic acid (10\% wt/wt), and sealed air-tight by a screw cap with a rubber septum. After $2 \mathrm{~h}$ at room temperature, the $\mathrm{CO}_{2}$ released from blood was measured in the headspace by means of gas isotope ratio mass spectrometry (Delta Plus XL, Thermo Quest, Bremen, Germany) coupled with the Gas Bench II (Finnigan, Bremen, Germany). The ${ }^{13} \mathrm{C}$ enrichment of $\mathrm{CO}_{2}$ was expressed as APE, calculated by differences between the ${ }^{13} \mathrm{C}$ abundance of plasma $\mathrm{CO}_{2}$ after and before ${ }^{13} \mathrm{C}$ tracer administration. Daily whole-body energy expenditure (EE) was calculated from the dilution curve of ${ }^{13} \mathrm{C}$ enrichments of $\mathrm{CO}_{2}$ in plasma after $\mathrm{NaH}\left[{ }^{13} \mathrm{C}\right] \mathrm{O}_{3}$ bolus injection using the formula: $\mathrm{EE}=[5.16+16.18 /$ $\mathrm{RQ}] \times \mathrm{V}\left(\mathrm{CO}_{2}\right)$, with $\mathrm{V}\left(\mathrm{CO}_{2}\right)=\left[\mathrm{D} / \mathrm{A}\left({ }^{13} \mathrm{C}\right)\right] \times \mathrm{REC}$ $\left({ }^{13} \mathrm{C}\right)$ (Elia et al., 1992; Junghans et al., 2007); $\mathrm{V}\left(\mathrm{CO}_{2}\right)$ is the $\mathrm{CO}_{2}$ production rate $(\mathrm{L} / \mathrm{d}), \mathrm{D}$ is the administered ${ }^{13} \mathrm{C}$ dose $(\mathrm{mol})$, and $\mathrm{A}\left({ }^{13} \mathrm{C}\right)$ is the calculated area under the ${ }^{13} \mathrm{C}$ enrichment-time curve. We used 0.71 as the ${ }^{13} \mathrm{C}$ recovery factor $\left[\operatorname{REC}\left({ }^{13} \mathrm{C}\right)\right]$ and 0.85 as the respiratory quotient (RQ; Figure 1). In detail, we applied the sum of 3 exponentials to fit the kinetics of ${ }^{13} \mathrm{C}$ enrichments. Nonlinear regression analysis based on a computer program (TableCurve, Systat Software GmbH, San Jose, CA) was used to determine the best-fit curve (P. Junghans; unpublished observations) and to estimate the parameters of the following equation:

\footnotetext{
${ }^{13} \mathrm{C}$ enrichment $=\mathrm{A}_{1} \mathrm{e}^{-\mathrm{k} 1 \times \mathrm{t}}+\mathrm{A}_{2} \mathrm{e}^{-\mathrm{k} 2 \times \mathrm{t}}+\mathrm{A}_{3} \mathrm{e}^{-\mathrm{k} 3 \times \mathrm{t}}$.
} 


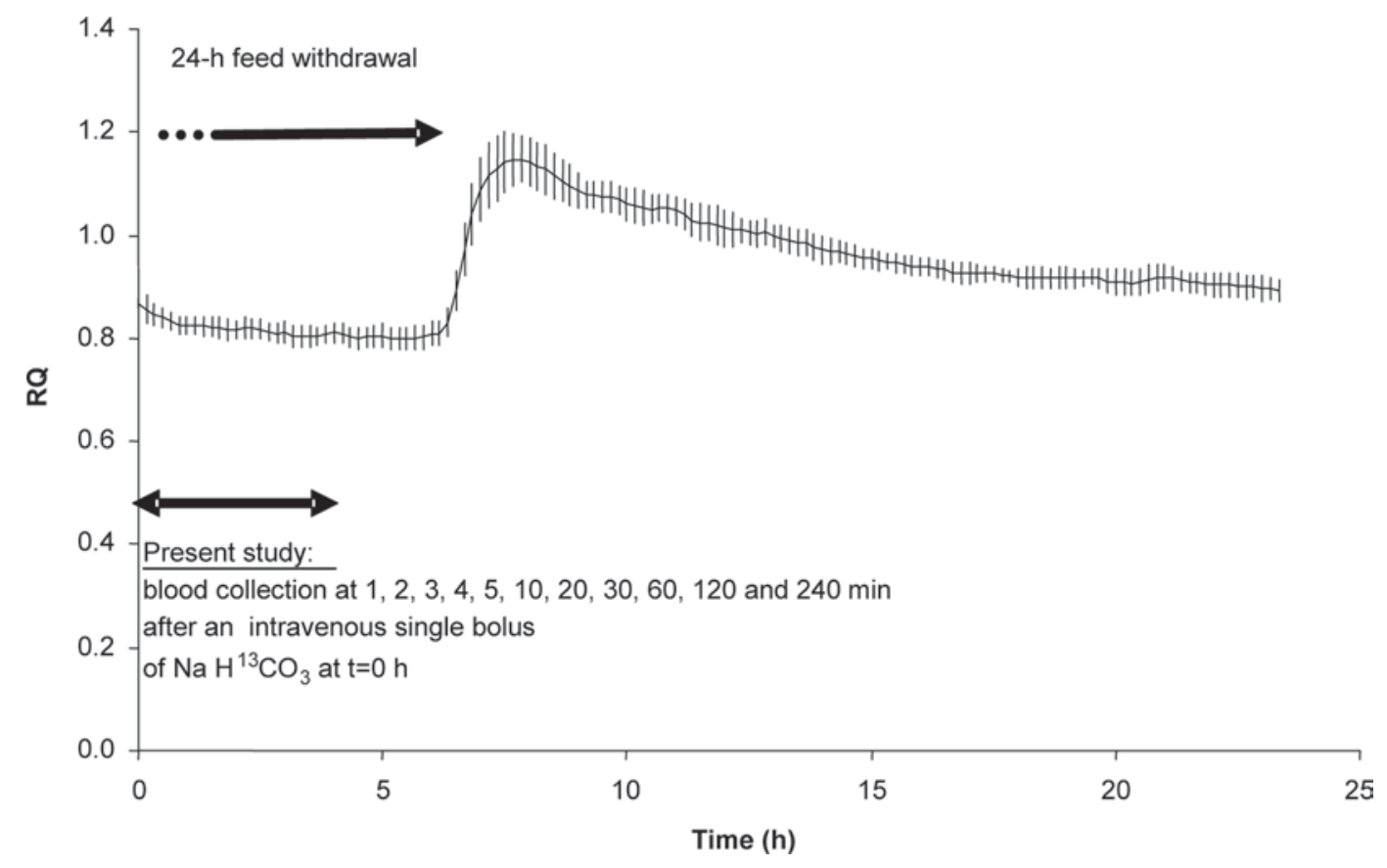

Figure 1. Respiratory quotient $(\mathrm{RQ} ;$ mean $\pm \mathrm{SD})$ in young bulls $(\mathrm{n}=12)$ after feed withdrawal and refeeding according to Junghans et al. (2007).

By integrating to $\mathrm{t}=\infty, \mathrm{A}\left({ }^{13} \mathrm{C}\right)$ results from

$$
\mathrm{A}\left({ }^{13} \mathrm{C}\right)=\mathrm{A}_{1} / \mathrm{k}_{1}+\mathrm{A}_{2} / \mathrm{k}_{2}+\mathrm{A}_{3} / \mathrm{k}_{3} .
$$

Glucose Tolerance Tests. Intravenous glucose tolerance tests $(\mathbf{G T T})$ were performed at the age of 8 mo. Bulls received jugular cannulas for blood sampling and, after a period of $12 \mathrm{~h}$ without food, glucose $(1 \mathrm{~g} / \mathrm{kg}$ of $\mathrm{BW}^{0.75}$ ) was infused into the jugular vein (Giesecke et al., 1987). Blood samples were taken before and 7, 14, 21 , and 28 min after glucose infusion. For insulin, blood samples were collected in tubes containing $1.6 \mathrm{mg}$ of potassium-EDTA $/ \mathrm{mL}$ of blood (Monovette, Sarstedt) and were put on crushed ice until centrifuged at 1,500 $\times g$ for 20 min at $4^{\circ} \mathrm{C}$. Supernatants were aliquoted and plasma aliquots were stored at $-20^{\circ} \mathrm{C}$ until analyzed. Insulin was measured by RIA using a porcine kit (PI12K, Linco Research, St. Charles, MO; Bellmann et al., 2004a). Cross-reactivity with bovine insulin was $90 \%$. Intra- and interassay coefficients of variation were 4.3 and $8.2 \%$, respectively. For glucose and insulin concentrations the area under the curves $\left(\mathbf{A} \mathbf{U} \mathbf{C}_{\text {gluc }}\right.$ and $\mathbf{A U C}_{\text {ins }}$ ) were calculated using the GraphPad computer program (GraphPad Software Inc., San Diego, CA). Basal concentrations were subtracted to calculate net AUC values.

\section{Carcass Characteristics}

All animals were slaughtered at 18 mo of age in the institute slaughterhouse. Carcasses were dissected and empty BW (EBW) and hot carcass weight (HCW) were measured as described by Pfuhl et al. (2007). Total dissected fat was calculated as the sum of omental, abdominal, perirenal, and subcutaneous fat. Inter- and intramuscular fat were not considered in this calculation. Muscle protein in all cuts (Pfuhl et al., 2007) was determined with near infrared spectroscopy, using an Infratec 1255 Food and Feed Analyzer (Foss Analytical A/S, Hillerød, Denmark). Furthermore, the carcasses were graded in beef conformation classes according to the European Commission regulation (E-U-R-O-P system), where grade $\mathrm{E}$ relates to excellent carcass conformation with high yield, and grade $\mathrm{P}$ relates to poor carcass confirmation with less yield. For statistical analysis, the letters were converted into integers, where the $\mathrm{E}$ grading corresponds to 1 , and the $\mathrm{P}$ grading to 5 (Pfuhl et al., 2007). In addition to yield grading, the carcasses were graduated within 5 fat classes according to the same regulation, where 1 indicates a lean carcass with less external fat and 5 a fat carcass with high amount of external fat (Pfuhl et al., 2007).

\section{Statistical Analysis}

Statistical evaluation was carried out with SPSS 15.0 for Windows (SPSS Inc., Chicago, IL). All variables were tested for normal distribution with the Kolmogoroff-Smirnoff test. Because all variables were normally distributed, data are presented as means \pm standard errors of the mean. Differences in the fat and meat 
classes (ordinal data) between families were tested with the Kruskal-Wallis test. Differences in the other variables (metric data) between families were tested with ANOVA or multivariate ANOVA (MANOVA) with family and (when appropriate) time as fixed effect. Differences were localized post hoc by the Tukey $t$-test. Correlations between variables were described using Spearman correlation coefficients for testing meat and fat classes and Pearson correlation coefficients for the other variables. Correlations were predicated on individual animals. We accepted statistical significance when $P<0.05$ for all tests, and trends were defined if $0.05<P<0.10$.

\section{RESULTS}

\section{BW and Feed Intake}

Interfamilial comparisons revealed that mean BW of the bulls at birth and at 8 mo of age did not differ between the 5 half-sib German Holstein $\times$ Charolais $\mathrm{F}_{2}$ crossbred families (Table 1). The ADG tended to vary starting at $7 \mathrm{mo}$ of age. At 10 to $12 \mathrm{mo}$, ADG was at maximum and higher $(P<0.05)$ in $\mathrm{Ba}$ than in $\mathrm{Cd}$, De, and Ec, resulting in highest $(P<0.05) \mathrm{BW}$ for $\mathrm{Ba}$ at 12 and 18 mo of age (Table 1). In contrast, DMI did not differ between families, either in the intake of concentrate or in the intake of hay, although feed intake generally increased with age in the first 12 mo of age (Table 1) and correlated with ADG and BW at lower ages (Table 2). Because feed composition (concentrate: hay ratio) did not differ between families, energy intake was related to DMI. Higher ADG and similar energy intake resulted in a lower FCR $(P<0.05)$ in Ba than in Ec (Table 1). In general, monthly BW were positively correlated with each other, whereas monthly ADG did not correspond with each other (Table 2). Correlations between monthly BW and ADG were found always at the same age classes and between ADG1 and BW2, ADG1 and BW3, and ADG2 and BW3 (where $1=7-9$ mo, $2=10-12$ mo, $3=13-18$ mo; Table 2 ).

\section{GTT and EE}

Plasma glucose and insulin concentrations increased after glucose infusion in all bulls, but did not show interfamilial differences (Table 3). Daily EE was higher $(P<0.01)$ at the age of 8 mo than at the age of 18 mo (Figure 2). Interfamilial comparison revealed differences in EE between the 5 German Holstein $\times$ Charolais $\mathrm{F}_{2}$ crossbred families $(P<0.05)$. At both time points, daily EE was lowest $(P<0.05)$ in Ba. At the age of 8 mo, EE was highest $(P<0.05)$ in $\mathrm{Cd}$ and $\mathrm{Ec}$, whereas at the age of 18 mo $\mathrm{EE}$ in $\mathrm{Ab}$ was found to be highest $(P<0.05)$ (Figure 2$)$. At the age of $8 \mathrm{mo}$, EE was negatively correlated with DMI1, with ADG2, and with $\mathrm{AUC}_{\text {ins }}$ (Table 2, Figure 3).

\section{Plasma Urea Kinetics}

In general, plasma urea concentrations increased with age $(P<0.001)$, were positively correlated with food intake $(\mathrm{r}=0.427, P<0.05)$, and differed between families $(P<0.001)$ (Table 4$)$. The Ba family showed the lowest and the De family the highest plasma urea concentrations at both ages, and plasma urea was always lower in Ba than in De $(P<0.05)$. Analyses of the urea kinetics using $\left[{ }^{15} \mathrm{~N}_{2}\right]$ urea dilution revealed that urea pool, urea flux, and urea loss differed among families, but showed no correlations with BW and ADG within age classes (Tables 2 and 4). Urea pool was larger in De than in $\mathrm{Ab}, \mathrm{Ba}$, and Ec $(P<0.001)$. Similarly, urea loss was higher in De than in $\mathrm{Ab}, \mathrm{Ba}$, and $\mathrm{Ec}(P<0.05)$. In contrast, urea flux was lower $(P<0.05)$ in De than in Ab. Urea flux was negatively correlated to DMI3 (Table 2).

\section{Carcass Characteristics}

Empty BW tended to be highest in Ba and lowest in De $(P<0.1$; Table 5). Subcutaneous fat in carcass was highest in Cd and lowest in De and Ec. Comparison of fat and beef conformation classes revealed differences in fat classes between families $(P<0.05$; Figure 4$)$. Here, bulls of $\mathrm{Ba}$ showed the least ranking in fat classes, whereas bulls of De showed the highest ranking in fat classes. The comparison of beef conformation classes revealed a tendency for De to show the highest ranking due to low protein content in the carcass and $\mathrm{Ab}$ showing the lowest ranking in beef conformation classes implying a high protein content in carcass $(P<0.1)$.

Empty BW and HCW were positively related to muscle protein in carcass $(\mathrm{r}=0.83$ and $0.91 ; P<0.001)$, and $\mathrm{HCW}$ was positively related to total fat content in carcass $(\mathrm{r}=0.32 ; P<0.05)$, subcutaneous fat $(\mathrm{r}=$ $0.38 ; P<0.01)$, and omental fat $(\mathrm{r}=0.32 ; P<0.05)$. Hot carcass weight and muscle protein in carcass were positively related to birth weight $(\mathrm{r}=0.34 ; P<0.01$, respectively) and to BW and ADG up to 18 mo (r $=0.27$ to $0.93 ; P<0.05$ or lower). The $\mathrm{AUC}_{\text {ins }}$ was positively related to abdominal fat in carcass $(\mathrm{r}=0.25$; $P<0.05)$. Urea loss was negatively related to absolute and relative muscle protein in carcass $(\mathrm{r}=-0.25$ and $-0.35 ; P<0.05$ and $P<0.001$, respectively) and was positively related to relative and absolute fat content in carcass $(\mathrm{r}=0.23$ and $0.29 ; P<0.1$ and $P<0.05)$.

\section{DISCUSSION}

The crossbreeding experiment with the 2 metabolically distinct cattle breeds - German Holstein and 
Table 1. Body weight, ADG, DMI, and feed conversion rate in 5 German Holstein $\times$ Charolais $\mathrm{F}_{2}$ crossbred families

\begin{tabular}{|c|c|c|c|c|c|c|c|}
\hline \multirow[b]{2}{*}{ Trait } & \multicolumn{5}{|c|}{ Family $^{1}$} & \multirow[b]{2}{*}{$\mathrm{SEM}^{2}$} & \multirow[b]{2}{*}{$P$-value } \\
\hline & $\mathrm{Ab}$ & $\mathrm{Ba}$ & $\mathrm{Cd}$ & De & Ec & & \\
\hline \multicolumn{8}{|l|}{$\mathrm{BW}, \mathrm{kg}$} \\
\hline Birth & 46.7 & 49.3 & 50.7 & 49.4 & 46.0 & 0.8 & 0.225 \\
\hline $8 \mathrm{mo}$ & 297.9 & 320.4 & 302.9 & 296.7 & 305.5 & 3.7 & 0.292 \\
\hline $12 \mathrm{mo}$ & $485.7^{\mathrm{ab}}$ & $520.6^{\mathrm{a}}$ & $478.1^{\mathrm{b}}$ & $476.7^{\mathrm{b}}$ & $482.4^{\mathrm{b}}$ & 4.8 & 0.016 \\
\hline $18 \mathrm{mo}$ & $693.7^{\mathrm{ab}}$ & $739.2^{\mathrm{a}}$ & $700.1^{\mathrm{ab}}$ & $676.7^{\mathrm{b}}$ & $688.6^{\mathrm{b}}$ & 5.6 & 0.020 \\
\hline \multicolumn{8}{|l|}{$\mathrm{ADG}, \mathrm{g} / \mathrm{d}$} \\
\hline $4-6 \mathrm{mo}$ & 1,042 & 1,165 & 1,046 & 1,026 & 1,069 & 1.8 & 0.132 \\
\hline 7-9 mo & 1,346 & 1,534 & 1,394 & 1,370 & 1,413 & 2.2 & 0.077 \\
\hline 10-12 mo & $1,539^{\mathrm{ab}}$ & $1,838^{\mathrm{a}}$ & $1,523^{\mathrm{b}}$ & $1,515^{\mathrm{b}}$ & $1,497^{\mathrm{b}}$ & 3.6 & 0.005 \\
\hline $13-15 \mathrm{mo}$ & 1,399 & 1,519 & 1,381 & 1,259 & 1,280 & 3.3 & 0.077 \\
\hline \multicolumn{8}{|l|}{$\mathrm{DMI},{ }^{3} \mathrm{~kg} / \mathrm{d}$} \\
\hline $4-6 \mathrm{mo}$ & 7.1 & 7.3 & 6.9 & 6.8 & 7.0 & 0.7 & 0.327 \\
\hline 7-9 mo & 9.1 & 9.4 & 9.0 & 9.4 & 9.3 & 0.9 & 0.769 \\
\hline $10-12 \mathrm{mo}$ & 10.4 & 11.1 & 11.1 & 11.0 & 10.5 & 0.9 & 0.114 \\
\hline $13-15 \mathrm{mo}$ & 9.3 & 9.8 & 10.1 & 9.6 & 9.8 & 1.1 & 0.472 \\
\hline \multicolumn{8}{|l|}{ Feed conversion ratio } \\
\hline $7-12 \mathrm{mo}$ & $8.4^{\mathrm{ab}}$ & $7.6^{\mathrm{b}}$ & $8.1^{\mathrm{ab}}$ & $8.4^{\mathrm{ab}}$ & $8.8^{\mathrm{a}}$ & 0.1 & 0.048 \\
\hline
\end{tabular}

${ }^{a, b}$ Means within a row with different superscripts differ $(P<0.05)$.

${ }^{1}$ The $64 \mathrm{~F}_{2}$ bulls investigated comprised 5 paternal half-sib families: $\mathrm{Ab}(\mathrm{n}=10), \mathrm{Ba}(\mathrm{n}=14), \mathrm{Cd}(\mathrm{n}=14), \mathrm{De}$ $(n=8)$, and Ec $(n=18)$. The uppercase letter represents the paternal origin of the $\mathrm{F}_{1}$ male and the lowercase letter represents paternal origin of the $\mathrm{F}_{1}$ female according to the $\mathrm{P}_{0}$ Charolais sires $\mathrm{A}, \mathrm{B}, \mathrm{C}, \mathrm{D}$, and $\mathrm{E}$.

${ }^{2} \mathrm{SEM}=$ pooled standard error of the mean.

${ }^{3}$ Sum of concentrate and hay intake.

Charolais - and utilization of segregating $\mathrm{F}_{2}$ offspring from 5 half-sib families enabled us to study body energy expenditure and urea kinetics in bulls with a combined dairy and beef genetic background. In general, in addition to variation among individuals, our results revealed remarkable differences among families concerning growth performance, energy expenditure, and urea plasma concentrations and kinetics as well as carcass classes. Interestingly, energy expenditure and urea kinetics showed no correlation with each other, which might indicate that they are not regulated by the same genetic mechanisms. In addition, the lack of common regulation might be a consequence of different growth rates for body protein and fat with age.

Regarding the relation to corresponding $\mathrm{F}_{2}$ sisters, bulls of $\mathrm{Ba}$ indicated the best growth performance, whereas heifers and cows of the Ba family showed the highest milk yield (Hammon et al., 2007, 2010). Because mammary gland development is related to growth potential (Sejrsen et al., 2000), our findings may

Table 2. Pearson rank correlations between BW, ADG, energy expenditure (EE), and urea kinetics (pool, flux, and loss) for different age classes $(1=7-9 \mathrm{mo}, 2=10-12 \mathrm{mo}, 3=13-18 \mathrm{mo}, \mathrm{A}=8 \mathrm{mo}, \mathrm{B}=18 \mathrm{mo})$

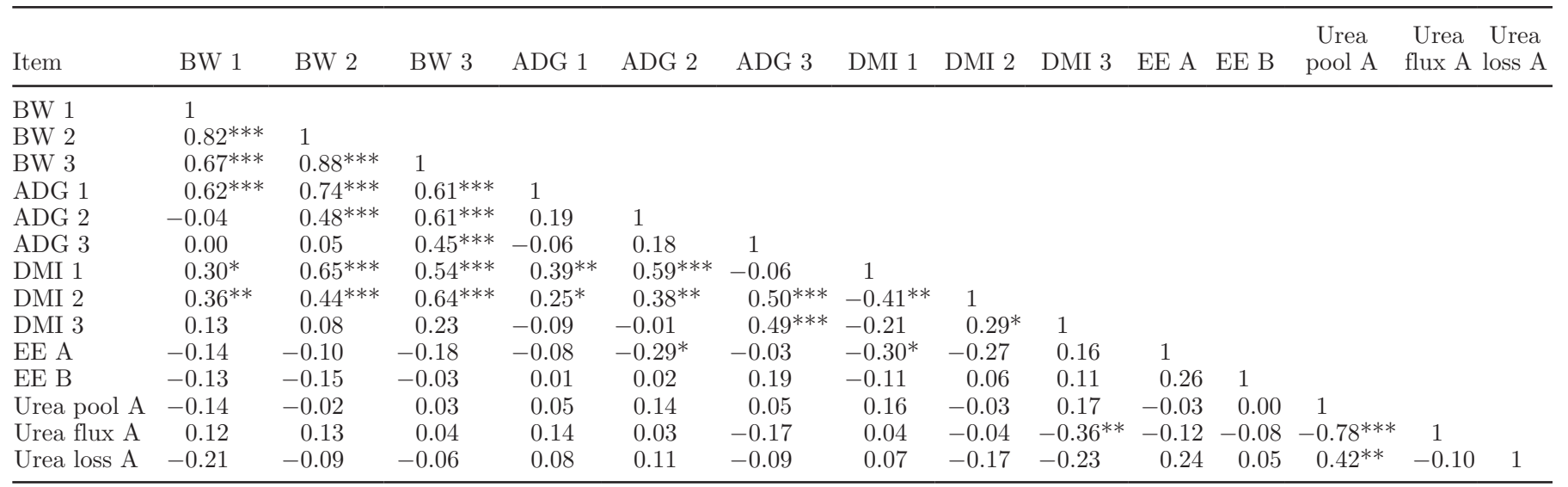

${ }^{1} \mathrm{r}_{\mathrm{p}}$-values are given: ${ }^{*} P<0.05 ;{ }^{* *} P<0.01 ;{ }^{* * *} P<0.001$. 
indicate a relationship between male growth potential and female mammary gland development and lactation performance within full-sib and half-sib $\mathrm{F}_{2}$ offspring. The lowest plasma glucose and insulin plasma concentrations as observed in lactating heifers of the Ba family were not confirmed by findings in Ba bulls, supporting the concept that changes in plasma glucose and insulin in Ba heifers are mainly related to milk production. A low insulin release after glucose challenge in $F_{2}$ heifers was associated with elevated milk production. In $\mathrm{F}_{2}$ bulls, a low insulin release was related to elevated energy expenditure. Because energy expenditure was not measured in $\mathrm{F}_{2}$ heifers, direct comparison between $\mathrm{F}_{2}$ bulls and heifers on energy expenditure are not possible. Interestingly, elevated insulin release after glucose challenge was associated with greater abdominal fat content in carcass of $\mathrm{F}_{2}$ bulls, whereas elevated insulin secretion was associated with a greater fat content in carcass in $\mathrm{F}_{2}$ cows (Hammon et al., 2010). These findings indicate the importance of insulin action on lipogenesis in both $\mathrm{F}_{2}$ males and females in our breeding experiment. Further relationships between half-sib $\mathrm{F}_{2}$ bulls and heifers were not conspicuous, because, with the exception of $\mathrm{Ba}$, all families indicated a comparable low lactation performance, whereas $\mathrm{F}_{2}$ heifers with milk yield comparable to that of Holstein cows were not seen (Hammon et al., 2007). Therefore, distribution of lactation performance among $\mathrm{F}_{2}$ females was quite different from distribution of growth performance among $\mathrm{F}_{2}$ males in our breeding model.

\section{Use of $\left[{ }^{15} \mathrm{~N}_{2}\right]$ Urea and $\mathrm{NaH}\left[{ }^{13} \mathrm{C}\right] \mathrm{O}_{3}$}

Measurements of energy expenditure in cattle using the ${ }^{13} \mathrm{C}$ bicarbonate dilution technique were previously performed in our lab, and we demonstrated that this technique is suitable to determine total energy expendi-

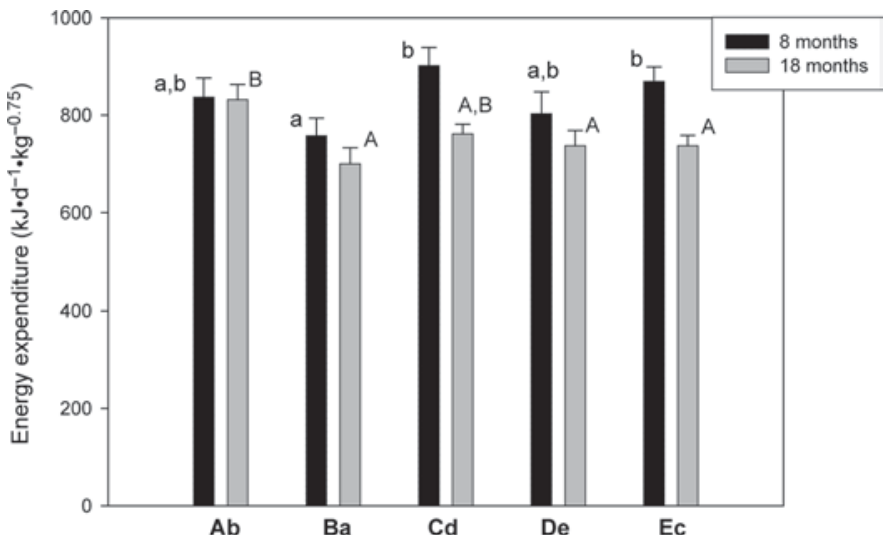

Figure 2. Energy expenditure of 8-mo-old (black bars) and 18-moold (gray bars) bulls in 5 German Holstein $\times$ Charolais $\mathrm{F}_{2}$ crossbred families (Ab, Ba, Cd, De, and Ec). Illustrated are means and standard errors. Means with different lowercase letters for $8 \mathrm{mo}$ and uppercase letters for $18 \mathrm{mo}$ are different (ANOVA with $P<0.05$ ).

ture in the whole body under natural conditions as well as in the barn and on pasture and finally to estimate energy requirements with $10 \%$ precision (Junghans et al., 2007; Kaufmann et al., 2009). Unfortunately, data on total energy expenditure measured via this novel ${ }^{13} \mathrm{C}$ bicarbonate dilution technique in other cattle breeding groups are not available yet, which hampers direct comparisons between breed types.

Measurements of urea metabolism in ruminants by using the $\left[{ }^{15} \mathrm{~N}_{2}\right]$ urea dilution techniques were described previously by Nolan and Leng $(1972,1974)$ and since then conducted by several other groups (Sarraseca et al., 1998; Lapierre and Lobley, 2001; Marini and van Amburgh, 2003; Hayashi et al., 2006; Shingu et al., 2007). Here, the calculation of urea pool sizes, urea flux, and urea loss provides important information on turnover rates of urea and provides advice on nitrogen metabolism. All parameters of urea metabolism can be

Table 3. Plasma glucose and insulin concentrations during glucose tolerance test at 8 mo in 5 German Holstein $\times$ Charolais $\mathrm{F}_{2}$ crossbred families

\begin{tabular}{|c|c|c|c|c|c|c|c|}
\hline \multirow[b]{2}{*}{ Trait } & \multicolumn{5}{|c|}{ Family $^{1}$} & \multirow[b]{2}{*}{$\mathrm{SEM}^{2}$} & \multirow[b]{2}{*}{$P$-value } \\
\hline & $\mathrm{Ab}$ & $\mathrm{Ba}$ & $\mathrm{Cd}$ & De & Ec & & \\
\hline \multicolumn{8}{|l|}{ Glucose } \\
\hline Basal concentration, mmol/L & 4.5 & 4.1 & 4.1 & 4.2 & 4.1 & 0.17 & 0.338 \\
\hline $\mathrm{AUC}_{\mathrm{Gluc}},{ }^{3} \mathrm{mmol} / \mathrm{L}$ & 155 & 139 & 154 & 166 & 147 & 6.7 & 0.124 \\
\hline \multicolumn{8}{|l|}{ Insulin } \\
\hline Basal concentration, $\mu \mathrm{g} / \mathrm{L}$ & 0.32 & 0.41 & 0.34 & 0.36 & 0.34 & 0.04 & 0.53 \\
\hline $\mathrm{AUC}_{\text {Ins }}, \mu \mathrm{g} / \mathrm{L}$ & 32.5 & 37.3 & 45.1 & 53.7 & 44.4 & 8.4 & 0.565 \\
\hline
\end{tabular}

${ }^{1}$ The $64 \mathrm{~F}_{2}$ bulls investigated comprised 5 paternal half-sib families: $\mathrm{Ab}(\mathrm{n}=10), \mathrm{Ba}(\mathrm{n}=14), \mathrm{Cd}(\mathrm{n}=14)$, De $(\mathrm{n}=8)$, and $\mathrm{Ec}(\mathrm{n}=18)$. The uppercase letter represents the paternal origin of the $\mathrm{F}_{1}$ male and the lowercase letter represents paternal origin of the $\mathrm{F}_{1}$ female according to the $\mathrm{P}_{0}$ Charolais sires $\mathrm{A}, \mathrm{B}, \mathrm{C}, \mathrm{D}$, and $\mathrm{E}$.

${ }^{2} \mathrm{SEM}=$ pooled standard error of the mean.

${ }^{3} \mathrm{AUC}=$ area under the curve. 

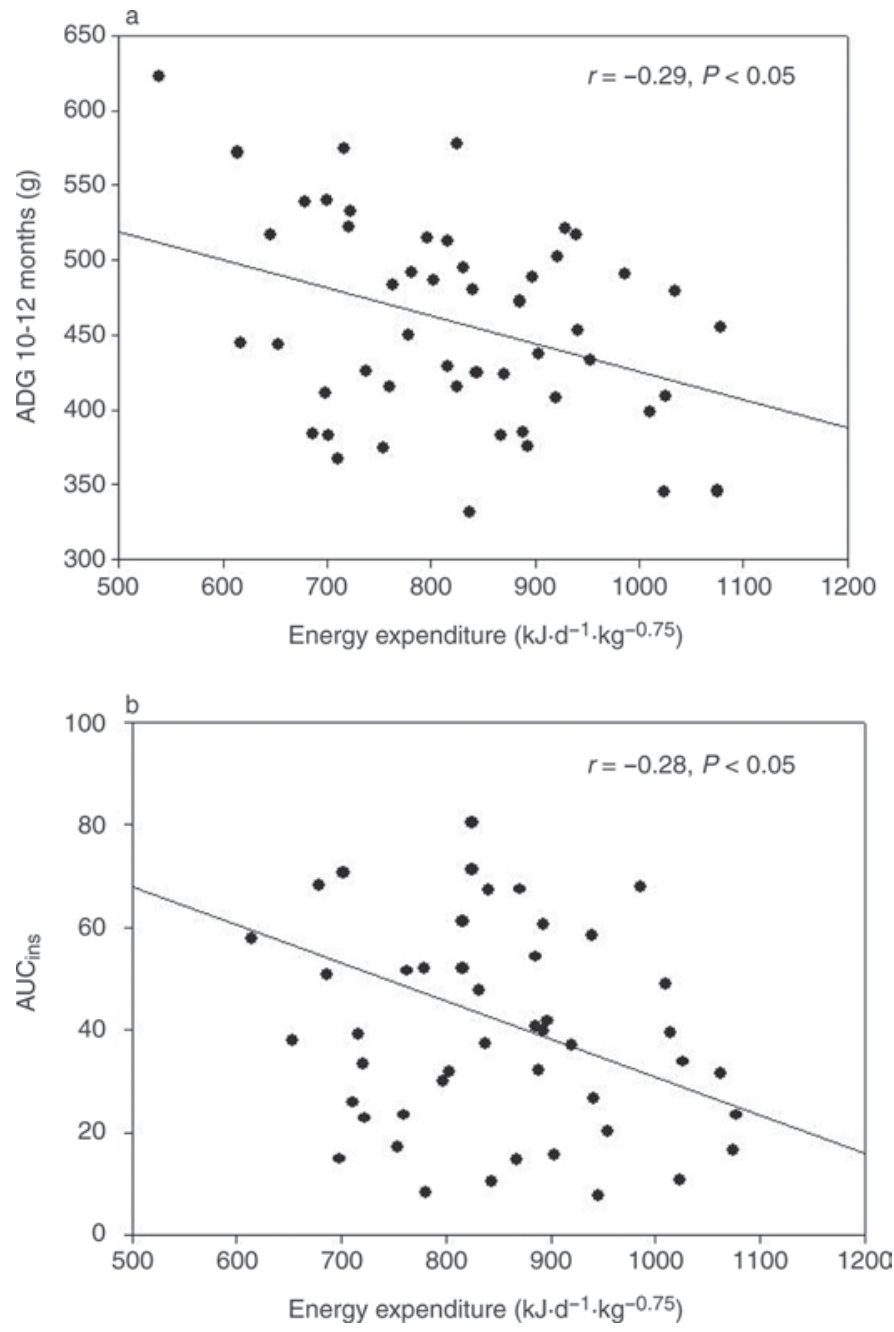

Figure 3. Illustration of correlations between a) energy expenditure and ADG at the age of $8 \mathrm{mo}$, and between b) energy expenditure and the area under the curve of insulin concentrations after glucose tolerance test $\left(\mathrm{AUC}_{\text {ins }}\right)$. influenced not only by dietary factors as energy:protein ratio and ruminal degradability of protein, but also by physiological conditions and nutrient requirements of the animal (Lapierre and Lobley, 2001). Furthermore, effects of animal variation exist, such as genetic differences in digestive or metabolic efficiency (Reynolds and Kristensen, 2008; Obitsu and Taniguchi, 2009), which we aimed to investigate in our crossbreeding experiment. Compared with milk cattle, beef breeds are usually characterized by a smaller urea pool sizes but higher urea irreversible loss rates, indicating enhanced availability of nitrogen sources in muscles and a greater level of nitrogen diffusion into the gastrointestinal tract (Shingu et al., 2007).

In our study, the same diets were given to all siblings of cattle. Differences in parameters of urea kinetics between families can most likely be attributed to physiological factors of animals.

\section{Energy Expenditure}

In our study, differences in EE represented differences in thermal losses, because bulls showed low physical activity and dietary-induced thermogenesis was low due to measurements being taken in the fasted state. There was a trend for an association of lower EE at 8 mo and higher ADG. Comparing families, the Ba family showed the lowest $\mathrm{EE}$ at ages 8 and $18 \mathrm{mo}$ and the highest ADG with a maximum at an age of 10 to 12 mo. Because DMI was not different among families, the low energy expenditure in the Ba family with regard to a high ADG demonstrated more efficient nutrient partitioning in this family. This is supported by the lowest FCR in the Ba family. Although data from meat and fat classes indicated a lean carcass in Ba, carcass data did not show significant differences among families

Table 4. Concentrations of blood urea $(8$ and $18 \mathrm{mo})$ and urea pool size, urea flux, and urea loss $(8$ mo $)$ in 5 German Holstein $\times$ Charolais $\mathrm{F}_{2}$ crossbred families

\begin{tabular}{|c|c|c|c|c|c|c|c|}
\hline Trait & \multicolumn{5}{|c|}{ Family $^{1}$} & $\mathrm{SEM}^{2}$ & $P$-value \\
\hline $8 \mathrm{mo}$ & $3.7^{\mathrm{ab}}$ & $3.5^{\mathrm{b}}$ & $3.9^{\mathrm{ab}}$ & $4.4^{\mathrm{a}}$ & $3.7^{\mathrm{ab}}$ & 0.1 & 0.029 \\
\hline $18 \mathrm{mo}$ & $5.1^{\mathrm{ab}}$ & $4.5^{\mathrm{b}}$ & $5.4^{\mathrm{ab}}$ & $5.9^{\mathrm{a}}$ & $5.0^{\mathrm{ab}}$ & 0.1 & 0.014 \\
\hline Urea pool, $\mathrm{mg} / \mathrm{kg}$ of $\mathrm{BW}^{0.75}$ & $109.7^{\mathrm{b}}$ & $116.5^{\mathrm{b}}$ & $126.4^{\mathrm{ab}}$ & $147.1^{\mathrm{a}}$ & $117.7^{\mathrm{b}}$ & 3.0 & 0.004 \\
\hline Urea flux, mg $/ \mathrm{kg}$ of $\mathrm{BW}^{0.75} / \mathrm{d}$ & $3,895.1^{\mathrm{a}}$ & $3,293.3^{\mathrm{ab}}$ & $3,032.3^{\mathrm{ab}}$ & $2,402.5^{\mathrm{b}}$ & $3,030.6^{\mathrm{ab}}$ & 126.0 & 0.032 \\
\hline
\end{tabular}

${ }^{\mathrm{a}, \mathrm{b}}$ Means within a row with different superscripts differ $(P<0.05)$.

${ }^{1}$ The $64 \mathrm{~F}_{2}$ bulls investigated comprised 5 paternal half-sib families: $\mathrm{Ab}(\mathrm{n}=10), \mathrm{Ba}(\mathrm{n}=14), \mathrm{Cd}(\mathrm{n}=14), \mathrm{De}(\mathrm{n}=8)$, and Ec $(\mathrm{n}=18)$. The uppercase letter represents the paternal origin of the $F_{1}$ male and the lowercase letter represents paternal origin of the $F_{1}$ female according to the $\mathrm{P}_{0}$ Charolais sires $\mathrm{A}, \mathrm{B}, \mathrm{C}, \mathrm{D}$, and $\mathrm{E}$.

${ }^{2} \mathrm{SEM}=$ pooled standard error of the mean. 
and were surprisingly not related to EE measurements. Empty BW tended to be highest in the Ba family, and EBW was closely related to muscle protein but not fat content in carcass. However, muscle protein in carcass was not different among families, even though it was numerically highest in the Ba family.

As mentioned before, data on the total EE measured via ${ }^{13} \mathrm{C}$ bicarbonate dilution technique are not available yet, which hampers direct comparisons. However, measurements of EE via indirect calorimetry, using respiration chambers, revealed lower EE in beef cattle compared with dairy cattle, mainly because of different energetic demands of muscle and adipose tissues (Vermorel et al., 1982; Jentsch et al., 1994, 1995; NRC, 1996; Williams and Jenkins, 2003; Derno et al., 2005). Energy requirement of Charolais bulls for maintenance, measured in respiration chambers, is less than that of Holstein bulls under thermo-neutral, energy-deficient conditions (Geay, 1984; Chudy, 2001). Thus, the lower total $\mathrm{EE}$ in the bulls of the Ba family seems to resemble the situation found in beef cattle. Accordingly, the better FCR and the higher ADG in the bulls of the Ba family matches the better growth rates observed in Charolais bulls (Pfuhl et al., 2007). On the other hand, the $\mathrm{Ba}$ sisters of our $\mathrm{F}_{2}$ resource population showed the highest milk production, which is more related to the Holstein breed than to the Charolais breed (Hammon et al., 2007, 2010). Therefore, clear allocation of $\mathrm{F}_{2}$ males and females to either beef or dairy metabolic type is not possible.

As expected, the post hoc test revealed that the $\mathrm{Ab}$ and $\mathrm{Ba}$ families, which originated from the same $\mathrm{P}_{0}$ Charolais bulls by mating sire A to paternal half sisters sired by B and vice versa (Kühn et al., 2002; Hammon

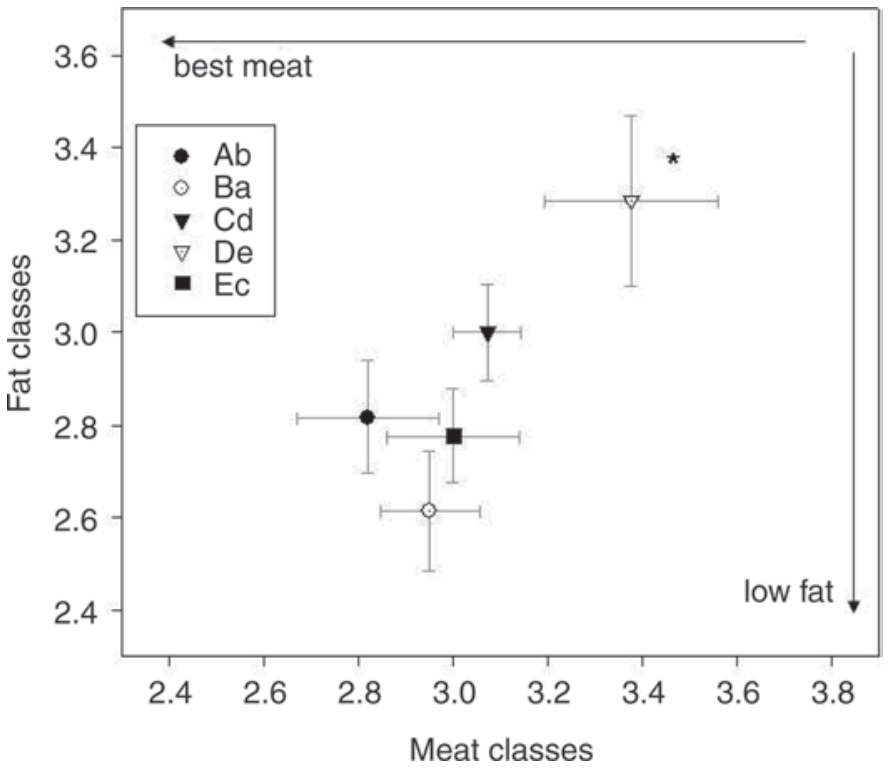

Figure 4. Fat classes and beef conformation classes at 18 mo of age in 5 German Holstein $\times$ Charolais $\mathrm{F}_{2}$ crossbred families (Ab, $\mathrm{Ba}, \mathrm{Cd}, \mathrm{De}, \mathrm{Ec})$. Values given as mean and pooled standard errors. *Significantly different in fat class (Kruskal-Wallis test with $P<$ $0.05)$.

et al., 2007), did not differ in BW, ADG, or carcass characteristics. However, at the age of $18 \mathrm{mo}$, the Ba family showed the lowest EE, whereas the Ab family showed the highest, which was not the case at 8 mo of age. The difference in total $\mathrm{EE}$ at the age of $18 \mathrm{mo}$ between $\mathrm{Ab}$ and $\mathrm{Ba}$ might result from greater changes in body composition at 18 mo than at 8 mo of age, although no significant differences in carcass composition were found. Because both families shared identical

Table 5. Carcass characteristics in 5 German Holstein $\times$ Charolais $\mathrm{F}_{2}$ crossbred families

\begin{tabular}{|c|c|c|c|c|c|c|c|}
\hline \multirow[b]{2}{*}{ Trait } & \multicolumn{5}{|c|}{ Family $^{1}$} & \multirow[b]{2}{*}{$\mathrm{SEM}^{2}$} & \multirow[b]{2}{*}{$P$-value } \\
\hline & $\mathrm{Ab}$ & $\mathrm{Ba}$ & $\mathrm{Cd}$ & De & Ec & & \\
\hline Empty BW, kg & 613 & 649 & 630 & 597 & 615 & 12.0 & 0.1 \\
\hline Hot carcass weight, $\mathrm{kg}$ & 395 & 416 & 404 & 389 & 397 & 9.5 & 0.4 \\
\hline Carcass weight/empty BW, $\%$ & 64.3 & 64 & 64.1 & 64.9 & 64.5 & 0.37 & 0.8 \\
\hline Muscle protein in carcass, kg & 58 & 61.5 & 57.9 & 56.4 & 59.1 & 1.8 & 0.4 \\
\hline Muscle protein/carcass weight, $\%$ & 14.7 & 14.8 & 14.3 & 14.5 & 14.9 & 0.2 & 0.2 \\
\hline Total fat in carcass, $\mathrm{kg}$ & 64 & 66.1 & 72 & 65.5 & 65.4 & 3.6 & 0.7 \\
\hline Total fat/carcass weight, $\%$ & 16.4 & 15.8 & 17.8 & 17.2 & 16.5 & 1.1 & 0.7 \\
\hline Subcutaneous fat, $\mathrm{kg}$ & $19.2^{\mathrm{ab}}$ & $19.7^{\mathrm{ab}}$ & $24.1^{\mathrm{a}}$ & $18.9^{\mathrm{b}}$ & $18.8^{\mathrm{b}}$ & 1.1 & 0.05 \\
\hline Omental fat, $\mathrm{kg}$ & 13.5 & 16.4 & 16.9 & 15.2 & 16.9 & 1.2 & 0.3 \\
\hline Abdominal fat, $\mathrm{kg}$ & 8.5 & 9.8 & 10.6 & 11.1 & 10.7 & 0.8 & 0.3 \\
\hline Perirenal fat, kg & 18.3 & 16 & 16.1 & 15.9 & 15.2 & 1.1 & 0.5 \\
\hline
\end{tabular}


but reciprocal paternal and maternal Charolais grandfathers, variation may additionally be caused by sex chromosomal effects or epigenetic differences (Hammon et al., 2007). Interestingly, the $\mathrm{F}_{2}$ females of these 2 families showed large differences in milk production and insulin responses during the first lactation (Hammon et al., 2007).

\section{Urea Kinetics}

Analyses of blood samples revealed increasing urea concentrations with age in all animals, which is probably mainly a result of less protein accretion and more body fat accretion with age, when diet and feed intake are the same, and greater surplus $\mathrm{N}$ that must be converted to urea and extracted. These findings are consistent with similar studies in cattle and goats (Gabler and Heinrichs, 2003; Marini and van Amburgh, 2003; Hayashi et al., 2006; Shingu et al., 2007). As mentioned above, beef cattle breeds are characterized by greater plasma urea concentrations and irreversible urea loss rates but lower urea pool size compared with dairy breeds (Matsuzaki et al., 1997; Shingu et al., 2007). This is based on enhanced availability of nitrogen sources in muscles and a greater level of nitrogen diffusion into the digestive tract compared with dairy cattle (Matsuzaki et al., 1997; Shingu et al., 2007). In our study, the Ba family indicated the lowest plasma urea concentrations but a lean carcass, and, although not significant, showed the highest muscle protein content in carcass. On the other hand, bulls of family De indicated the highest plasma urea concentrations and the highest urea loss, but the lowest urea pool. Muscle protein content in carcass was numerically lowest in De. In addition, an overall negative relationship was observed between urea loss and muscle protein content in carcass, indicating an association between urea kinetics and body protein accretion. In general, urea metabolism and consequently nitrogen metabolism can be influenced by dietary factors, by physiological conditions, and by genetic differences in digestive and metabolic efficiency (Lapierre and Lobley, 2001; Reynolds and Kristensen, 2008; Obitsu and Taniguchi, 2009). Because all bulls were raised under the same environmental conditions and DMI did not differ between families, the results suggest differences in nitrogen partitioning among families in this study.

In conclusion, we demonstrated that in segregating Holstein $\times$ Charolais crossbred bulls differences in growth performance were related to differences in energy expenditure. Relationships of energy expenditure and urea kinetics to carcass composition were not strong, but might increase when more $\mathrm{F}_{2}$ bulls are available. Furthermore, findings on growth performance in $\mathrm{F}_{2}$ bulls indicated a relationship to lactation performance in $\mathrm{F}_{2}$ full-sib and half-sib heifers and cows; this relationship needs further investigation.

\section{ACKNOWLEDGMENTS}

We thank F. Becker (DVM, Research Unit Reproductive Biology, FBN Dummerstorf), M. Spitschak (DVM, Research Unit Molecular Biology, FBN Dummerstorf), and D. Krüger (DVM, Rostock, Germany) for performing the embryo transfer, and G. Klautscheck and the staff at the Research Farm of our institute for rearing the $\mathrm{F}_{2}$ bulls. We also thank S. Görs, A. Schulz, K. Karparti, C. Fiedler, and I. Rothe of the Research Units Nutritional Physiology and Muscle Biology and Growth (FBN Dummerstorf) for data collection and their support.

\section{REFERENCES}

AfB. 1998. Mitteilung des Ausschusses für Bedarfsnormen der Gesellschaft für Ernährungsphysiologie. Herausgeber M. Kirchgeßner. Proc. Soc. Nutr. Physiol. 7:141-150.

Bauman, D. E., and W. B. Currie. 1980. Partitioning of nutrients during pregnancy and lactation: A review of mechanisms involving homeostasis and homeorhesis. J. Dairy Sci. 63:1514-1529.

Bellmann, O., J. Wegner, C. Rehfeldt, F. Teuscher, F. Schneider, J. Voigt, M. Derno, H. Sauerwein, J. Weingartner, and K. Ender. 2004a. Beef versus dairy cattle: A comparison of metabolically relevant hormones, enzymes, and metabolites. Livest. Prod. Sci. $89: 41-54$.

Bellmann, O., J. Wegner, F. Teuscher, F. Schneider, and K. Ender. 2004b. Muscle characteristics and corresponding hormone concentrations in different types of cattle. Livest. Prod. Sci. 85:45-57.

Chudy, A. 2001. Energy and protein metabolism under thermoneutral, energy deficient and protein surplus conditions in genetically different growing bulls (Charolais and German Holstein (Friesian)). Pages 365-368 in Proc. 15th Symp. on Energy Metabolism in Animals, A. Chwalibog, and K. Jakobsen, ed. EAAP Publication 103. Wageningen Academic Publisher, Wageningen, the Netherlands.

Cronjé, P. B. 2000. Nutrient-gene interactions: Future potential and applications. Pages 409-422 in Ruminant Physiology: Digestion, Metabolism, Growth and Reproduction. P. B. Cronjé, ed. CAB International, Wallingford, UK.

Derno, M., W. Jentsch, M. Schweigel, S. Kuhla, C. C. Metges, and H. D. Matthes. 2005. Measurements of heat production for estimation of maintenance energy requirements of Hereford steers. J. Anim. Sci. 83:2590-2597.

Elia, M., N. K. Fuller, and P. R. Murgatroyd. 1992. Measurement of bicarbonate turnover in humans: Applicability to estimation of energy expenditure. Am. J. Physiol. 263:E676-E687.

Gabler, M. T., and A. J. Heinrichs. 2003. Effects of increasing dietary protein on nutrient utilization in heifers. J. Dairy Sci. 86:21702177.

Geay, Y. 1984. Energy and protein-utilization in growing cattle. J. Anim. Sci. 58:766-778.

Giesecke, D., M. Stangassinger, and W. Veitinger. 1987. PlasmaInsulin und Insulinantwort bei Kühen mit hoher Milchleistung. Fortsch. Tierphysiol. Tierernähr. 18:20-30.

Hammon, H. M., O. Bellmann, J. Voigt, F. Schneider, and C. Kühn. 2007. Glucose-dependent insulin response and milk production in heifers within a segregating resource family population. J. Dairy Sci. 90:3247-3254.

Hammon, H. M., C. C. Metges, A. Schulz, P. Junghans, J. Steinhoff, F. Schneider, R. Pfuhl, R. M. Bruckmaier, R. Weikard, and C. Kühn. 2010. Differences in milk production, glucose metabolism, and carcass composition of two Charolais $\times$ Holstein $\mathrm{F}_{2}$ families 
derived from reciprocal paternal and maternal grandsire crosses. J. Dairy Sci. 93:3007-3018.

Hayashi, H., M. Kawai, I. Nonaka, F. Terada, K. Katoh, and Y. Obara. 2006. Developmental changes in the kinetics of glucose and urea in Holstein calves. J. Dairy Sci. 89:1654-1661.

Istasse, L., C. van Eenaeme, P. Evrard, A. Gabriel, P. Baldwin, G. Maghuin-Rogister, and J. M. Bienfait. 1990. Animal performance, plasma hormones and metabolites in Holstein and Belgian Blue growing-fattening bulls. J. Anim. Sci. 68:2666-2673.

Jentsch, W., M. Derno, H. D. Matthes, B. Lohrke, S. Kuhla, and H. Scholze. 1995. Results from measurements of nitrogen and energy-metabolism in adaptive different cattle. Arch. Tierernahr. 48:159-171.

Jentsch, W., H. D. Matthes, M. Derno, J. Wegner, J. Voigt, B. Lohrke, K. Nurnberg, and M. Beyer. 1994. Studies on nutrients metabolism, heat-production, behavior and morphology of growing bulls of the breeds Galloway and Black-White dairy cattle. Arch. Anim. Breed. 37:363-375.

Junghans, P., M. Derno, M. Gehre, R. Höfling, P. Kowski, G. Strauch, W. Jentsch, J. Voigt, and U. Hennig. 1997. Calorimetric validation of C-13 bicarbonate and doubly labelled water method for determining the energy expenditure in goats. Z. Ernahrungswiss. $36: 268-272$.

Junghans, P., J. Voigt, W. Jentsch, C. C. Metges, and M. Derno. 2007. The C-13 bicarbonate dilution technique to determine energy expenditure in young bulls validated by indirect calorimetry. Livest. Sci. 110:280-287.

Kaufmann, L. D., A. Münger, M. Rérat, P. Junghans, S. Görs, C. C. Metges, and F. Dohme. 2009. Differences in energy expenditure, physical activity and feeding behaviour between grazing cows and cows fed grass indoors. Proc. Soc. Nutr. Physiol. 18:51. (Abstr.)

Kühn, C., O. Bellmann, J. Voigt, J. Wegner, V. Guiard, and K. Ender. 2002. An experimental approach for studying the genetic and physiological background of nutrient transformation in cattle with respect to nutrient secretion and accretion type. Arch. Anim. Breed. 45:317-330.

Lachica, M., and J. F. Aguilera. 2003. Estimation of energy needs in the free-ranging goat with particular reference to the assessment of its energy expenditure by the ${ }^{13} \mathrm{C}$-bicarbonate method. Small Rumin. Res. 49:303-318.

Lapierre, H., and G. E. Lobley. 2001. Nitrogen recycling in the ruminant: A review. J. Dairy Sci. 84:223-236.

Marini, J. C., and M. E. van Amburgh. 2003. Nitrogen metabolism and recycling in Holstein heifers. J. Anim. Sci. 81:545-552.

Matsuzaki, M., S. Takizawa, and M. Ogawa. 1997. Plasma insulin, metabolite concentrations, and carcass characteristics of Japanese Black, Japanese Brown, and Holstein steers. J. Anim. Sci. 75:3287-3293

Merchen, N. R. 1993. Digestion, absorption, and excretion in ruminants. Pages 172-201 in The Ruminant Animal: Digestive Physiol- ogy and Nutrition. D. C. Church, ed. Waveland Press, Long Grove, IL.

Nolan, J. V., and R. A. Leng. 1972. Dynamic aspects of ammonia and urea metabolism in sheep. Br. J. Nutr. 27:177-194.

Nolan, J. V., and R. A. Leng. 1974. Isotope techniques for studying dynamics of nitrogen-metabolism in ruminants. Proc. Nutr. Soc. $33: 1-8$.

NRC. 1996. Nutrient Requirements of Beef Cattle. 7th ed. National Academy Press, Washington, DC.

Obitsu, T., and K. Taniguchi. 2009. Quantitative comparison of diversity and conformity in nitrogen recycling of ruminants. Asianaustralas. J. Anim. Sci. 22:440-447.

Pareek, N., J. Voigt, O. Bellmann, F. Schneider, and H. M. Hammon. 2007. Energy and nitrogen metabolism and insulin response to glucose challenge in lactating German Holstein and Charolais heifers. Livest. Prod. Sci. 112:115-122.

Pfuhl, R., O. Bellmann, C. Kühn, F. Teuscher, K. Ender, and J. Wegner. 2007. Beef versus dairy cattle: A comparison of feed conversion, carcass composition, and meat quality. Arch Anim. Breed. 50:59-70.

Reynolds, C. K., and N. B. Kristensen. 2008. Nitrogen recycling through the gut and the nitrogen economy of ruminants: An asynchronous symbiosis. J. Anim. Sci. 86(E-Suppl.):E293-E305.

Sarraseca, A., E. Milne, M. J. Metcalf, and G. E. Lobley. 1998. Urea recycling in sheep: Effects of intake. Br. J. Nutr. 79:79-88.

Sejrsen, K., S. Purup, M. Vestergaard, and J. Foldager. 2000. High body weight gain and reduced bovine mammary growth: Physiological basis and implications for milk yield potential. Domest. Anim. Endocrinol. 19:93-104.

Shingu, H., H. Hayashi, E. Touno, A. Oshibe, S. Kushibiki, S. Oda, K. Katoh, and Y. Obara. 2007. Characteristics of developmental changes in the kinetics of glucose and urea in Japanese Black calves: Comparison with Holstein calves. J. Anim. Sci. 85:29102915.

Vermorel, M., Y. Geay, and J. Robelin. 1982. Energy utilization by growing bulls, variations with genotype, live weight, feeding level and between animals. Pages 88-89 in Energy Metabolism of Farm Animals. EAAP Publ, Agric. Univ. of Norway, Norway.

Voigt, J., and H. Steger. 1967. Quantification of ammonia, urea and ketone bodies in biological materials with a modified micro diffusion apparatus. Arch. Anim. Nutr. 17:289-293.

Williams, C. B., and T. G. Jenkins. 2003. A dynamic model of metabolizable energy utilization in growing and mature cattle. I. Metabolizable energy utilization for maintenance and support metabolism. J. Anim. Sci. 81:1371-1381.

Zitnan, R., J. Voigt, S. Kuhla, J. Wegner, A. Chudy, U. Schönhusen, M. Brna, M. Zupcanova, and H. Hagemeister. 2008. Morphology of small intestinal mucosa and intestinal weight change with metabolic type of cattle. Vet. Med. 53:523-532. 